\title{
REVIEW
}

\section{Global review of shark and ray entanglement in anthropogenic marine debris}

\author{
Kristian J. Parton ${ }^{1, *}$, Tamara S. Galloway ${ }^{2}$, Brendan J. Godley ${ }^{1}$ \\ ${ }^{1}$ Centre for Ecology and Conservation, School of Biosciences, University of Exeter, Penryn Campus, Penryn, \\ Cornwall TR10 9EZ, UK \\ ${ }^{2}$ Biosciences, College of Life and Environmental Sciences, Geoffrey Pope Building, University of Exeter, Stocker Road,
} Exeter, Devon EX4 4QD, UK

\begin{abstract}
Numerous marine taxa become entangled in anthropogenic marine debris, including cartilaginous fishes (class: Chondrichthyes, e.g. elasmobranchs [sharks, skates and rays], holocephalans [chimaeras]). Here we review research that has been conducted on the susceptibility of these taxa to entanglement in marine debris by conducting a systematic literature review complemented by novel data collection from the social media site Twitter. Our literature review yielded 47 published elasmobranch entanglement events ( $\mathrm{N}=557$ animals) in 26 scientific papers, with 16 different families and 34 species in all 3 major ocean basins affected. The most common entangling objects were ghost fishing gear (74\% of animals) followed by polypropylene strapping bands $(11 \%$ of animals), with other entangling materials such as circular plastic debris, polythene bags and rubber tyres comprising $1 \%$ of total entangled animals. Most cases were from the Pacific and Atlantic oceans (49 and $46 \%$, respectively), with a bias towards the USA ( $44 \%$ of animals), the UK (30\% of animals) and South Africa (10\% of animals). While investigating Twitter, we found 74 cases of elasmobranch entanglement, representing 14 families and 26 species. On Twitter, ghost fishing gear was again the most common entangling material (94.9\% of animals), with the majority of entanglement records originating from the Atlantic Ocean (89.4\% of total entangled animals). Entanglement in marine debris is symptomatic of a degraded marine environment and is a clear animal welfare issue. Our evidence suggests, however, that this issue is likely a far lesser threat to this taxon than direct or indirect take in marine fisheries. We highlight a relative paucity of scientific data on this subject and recommend a standardisation of reporting in an attempt to accurately quantify elasmobranch entanglement risks and locate interaction hotspots.
\end{abstract}

KEY WORDS: Sharks · Rays · Elasmobranch $\cdot$ Marine debris $\cdot$ Ghost fishing $\cdot$ Entanglement

\section{INTRODUCTION}

\subsection{Plastic in the marine environment}

Globally, anthropogenic debris in the marine environment is increasing (Derraik 2002), with the majority of debris consisting of plastic materials (Gregory \& Ryan 1997, Derraik 2002, Galgani et al. 2015). Plastic is now being found in all sections of the water column, from the epipelagic zone at the surface to the

\footnotetext{
*Corresponding author: kp336@exeter.ac.uk
}

deep sea trenches of the hadopelagic zone, in all of the world's oceans (Gregory 1996, Derraik 2002, Cole et al. 2011, Fischer et al. 2015, Bond et al. 2018). Plastic is inexpensive to produce, lightweight, durable and efficient in its uses (Ryan et al. 2009). Unfortunately, it is these properties, in conjunction with its disposable nature, rapid consumption by humans and poor waste governance, that leads to its presence and persistence in oceans, estimated as taking hundreds of years to degrade (Barnes et al. 2009).

() The authors 2019. Open Access under Creative Commons by Attribution Licence. Use, distribution and reproduction are unrestricted. Authors and original publication must be credited. 
Between 4.8 and 12.7 million tonnes of plastic are estimated to enter the marine environment every year, and without appropriate waste management strategies, this number could increase substantially in the coming years (Jambeck et al. 2015).

Marine life engages with plastic in numerous ways, with nearly 700 marine species interactions reported (Gall \& Thompson 2015). The major threats of plastic to marine life revolve around ingestion and entanglement (Laist 1997, Cliff et al. 2002, Page et al. 2004, Votier et al. 2011, Barreiros \& Raykov 2014, Vegter et al. 2014, Lawson et al. 2015, Nelms et al. 2018), alongside potential wider ecosystem effects such as habitat degradation (Shahidul Islam \& Tanaka 2004, Nelms et al. 2016).

The marine environment is littered with various types of debris that result in the entanglement of elasmobranchs. Broadly these can be categorised into 2 groups: fishing-based sources of debris and other land-based sources of debris (Duncan et al. 2017). Fishing equipment is often lost at sea due to wear and tear over time or inclement weather conditions (Gilman 2015). This equipment can be defined as abandoned, lost or discarded fishing gear (Gilman 2015, Wilcox et al. 2015). It is also described by the term ghost fishing gear, which has the potential to passively drift across oceans, often continuing to capture a variety of marine life (Macfadyen et al. 2009, Duncan et al. 2017). The second category encompasses other sources of debris, often items used by humans on land; these include plastic packing straps, plastic bags and other packaging. These items enter oceans via a number of land-based outputs, often as a result of poor waste management (Jambeck et al. 2015).

Fish aggregating devices (FADs) also entangle marine species (Franco et al. 2009, Filmalter et al. 2013, Poisson et al. 2014). FADs are often created in conjunction with tuna purse seine fisheries in an attempt to attract fish species into a confined area before encircling them within the purse seine nets (Fonteneau et al. 2000, Ménard et al. 2000). They are intentionally created to attract large numbers of target species and often indiscriminately entangle larger species of marine fauna including elasmobranchs (Filmalter et al. 2013, Poisson et al. 2014). FADs can be moored to the ocean floor or can be free drifting (drifting fish aggregating devices, DFADs), equipped with electronic buoys to allow remote monitoring across the ocean (Maufroy et al. 2015). Many DFADs have large quantities of netting hanging several metres below the surface to create drag, ensuring their direction is determined by ocean currents as opposed to wind (Filmalter et al. 2013).

\subsection{Elasmobranchs and anthropogenic debris}

Sharks and rays generally display life history traits such as late maturation (Heppell et al. 1996), low reproductive output (Pardini et al. 2001) and long life span (Cailliet et al. 2001), making them highly susceptible to overexploitation (Adams 1980, Stevens et al. 2000, Pearson et al. 2014). Elasmobranchs are one of the most threatened taxa in the marine environment, with $24 \%$ of elasmobranch populations considered as threatened with extinction from a variety of anthropogenic threats (Dulvy et al. 2014). Bycatch and targeted shark fisheries pose 2 of the greatest threats to shark populations across the globe, and it is estimated that between 63 and 273 million sharks are killed annually through a variety of fishing practices; however, fully quantifying shark decline and risk of extinction has been challenging, predominately due to a lack of scientific data (Worm et al. 2013).

Entanglement of elasmobranchs in marine debris is relatively understudied within the scientific literature (Stelfox et al. 2016), with only a handful of studies investigating the problems elasmobranchs face regarding entanglement in plastic pollution (Laist 1997, Seitz \& Poulakis 2006, Wegner \& Cartamil 2012, Stelfox et al. 2016). Elasmobranchs are suggested to be less vulnerable to plastic pollution than other large marine species; however, this could be a consequence of a lack of studies rather than an inherently lower susceptibility (Stelfox et al. 2016). Of the studies which have been conducted on the topic of plastic ingestion, several have highlighted that large filter-feeding elasmobranchs may be particularly vulnerable to this threat (Fossi et al. 2014, 2017, Germanov et al. 2018). Only a few studies have touched on the categories of anthropogenic debris that may entangle elasmobranchs the most, with a particular focus on ghost fishing gear (Gilman 2015, Stelfox et al. 2016). If elasmobranchs are susceptible to entanglement in anthropogenic debris, this could have potential negative implications on rapidly declining populations. Entanglement can lead to starvation, suffocation, immobilisation and ultimately death (Laist 1997, Gall \& Thompson 2015), making this unequivocally an animal welfare issue, if not of conservation relevance.

\subsection{Social media site Twitter}

A rise in the use of social media in the last 10 years has transformed the ability of participants to document and share information about the natural world. 
Social media websites have begun to open the eyes of many regarding some of the threats animals face in the environment, with certain viral messages, photos and videos reaching audiences of millions. Websites such as Twitter, YouTube and Facebook have become potential digital scientific databases, and researchers are now beginning to use these data to aid their own scientific research (Davies et al. 2012). Twitter allows users to post messages, or tweets, of up to 280 characters as well as other accompanying photographs or videos. Those working in the marine sector, alongside members of the public, often tweet about marine conservation issues that they experience day to day. This can provide real-time data on issues such as entanglement, strandings, beach debris and bycatch that can be accessed quickly and easily by anyone registered to the website (Shiffman 2018).

In this review, we define elasmobranch entanglement as the process by which any cartilaginous fish (including sharks, rays and chimaera) becomes entwined or trapped within anthropogenic debris - excluding those bycaught in active fishing gear. The aim of this study was to (1) assess to what extent elasmobranchs are impacted by marine debris by reviewing existing, and obtaining new, reports of the occurrence and global spatial distribution of elasmobranch entanglement; (2) gain insights into which families are most at risk, whilst also highlighting the ocean basins where elasmobranch entanglement is most prevalent; and (3) determine the categories of plastic debris that are most impacting elasmobranchs via entanglement.

\section{METHODS}

\subsection{Literature review}

Between November 2017 and May 2018, and again in March 2019, scientific literature was reviewed for records of elasmobranch entanglement in marine anthropogenic debris. We searched the Institute for Scientific Information's Web of Science for the terms plastic, macroplastic, marine debris, entanglement, entrapment, ghost nets, ghost fishing and fish aggregating device. Each of these terms was paired with chimaera, elasmobranch, shark, ray, stingray, mobula, manta, sawfish and guitarfish. Most search terms returned with fewer than 30 results, and many returned with no results. In total, after filtering for erroneous entries, this resulted in 20 publications. Additionally, the top 200 search results for these terms on Google Scholar (for each decade between 1940 and
2019) were scanned to locate any papers that may have been missed in the initial search process; this yielded an additional 6 papers to add to the review. Information on species, location and entangling debris was recorded where possible. The authors note that sawfish are not by definition a marine species of elasmobranch but are included due to their high susceptibility to entanglement in anthropogenic debris.

Duncan et al. (2017) highlight the clear need to differentiate between entanglement and bycatch. Bycatch is known to be defined as the unselective catch of either unused or unmanaged species during fishing (Davies et al. 2009), with a particular focus on active gear, whereas ghost gear can be defined as 'when the fisher has lost operational control of the equipment' (Duncan et al. 2017, see also Smolowitz 1978). Similarly in the present study, only elasmobranchs caught in passive ghost fishing gear were considered to be entangled animals; bycaught animals were not considered here.

\subsection{Twitter search}

To complement published work, we searched Twitter between 2009 and 2019 (from the first recorded tweet about elasmobranch entanglement), featuring the same terms used in our literature search. In total, 74 relevant tweets were recorded and investigated further. Again, information on species, location and entangling debris was recorded where possible, directly through the tweet itself or through any other associated images and URL links.

Certain publications reported shark entanglement in DFADs/FADs; however, it is unknown whether the sharks became passively entangled in the netting as the DFAD was drifting or whether the sharks became entangled after being encircled in the purse seine nets. Some papers were therefore omitted from this review.

\section{RESULTS}

\subsection{Extent of impact}

Research on sharks and rays has been steadily increasing over time. Sharks in particular have become a topic of intense research in the last 30 years, with thousands of papers released yearly (Fig. 1A). Entanglement papers, as a proportion of overall papers on these taxa, however, remain relatively low (Fig. 1B). We recorded 47 entanglement 

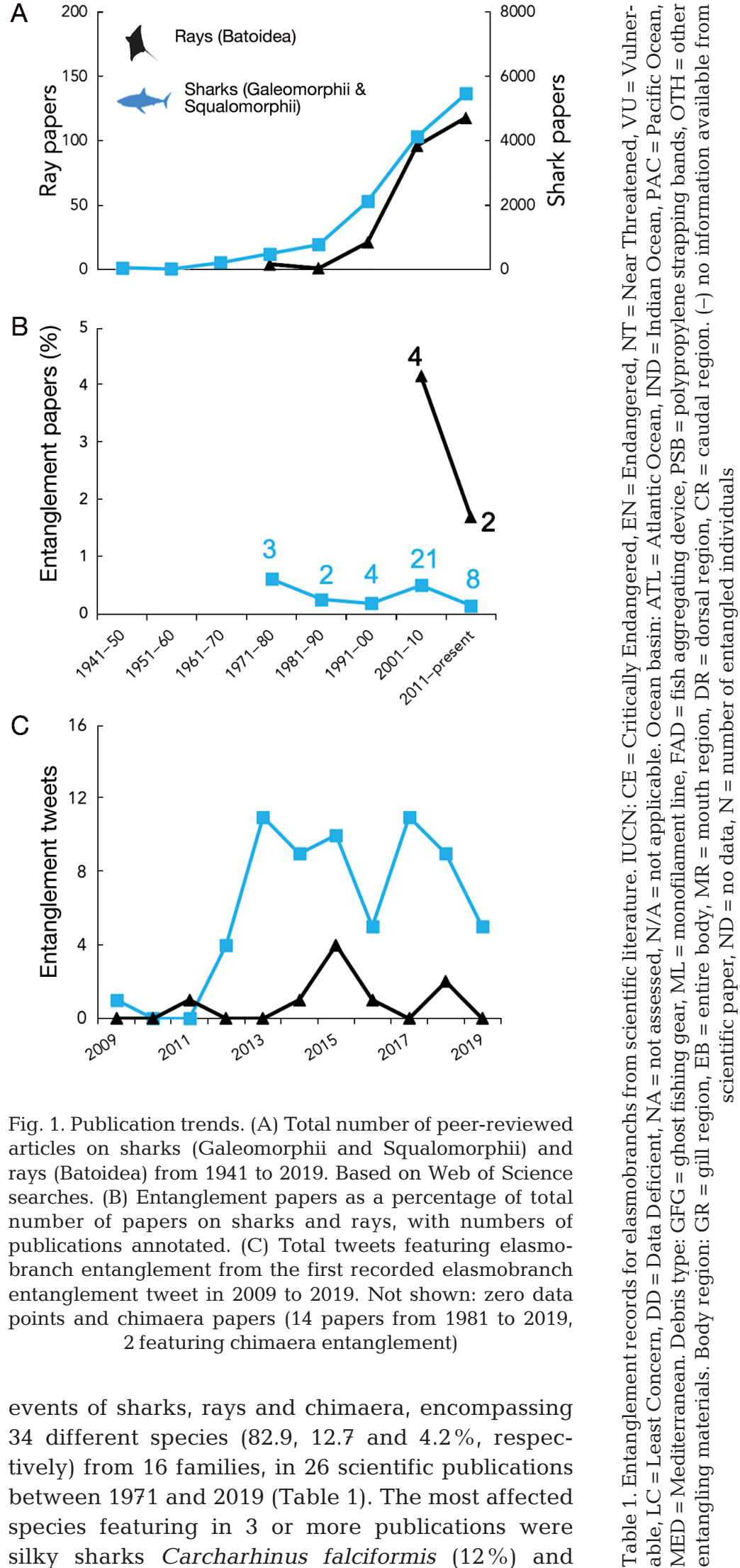

Table continued on next page

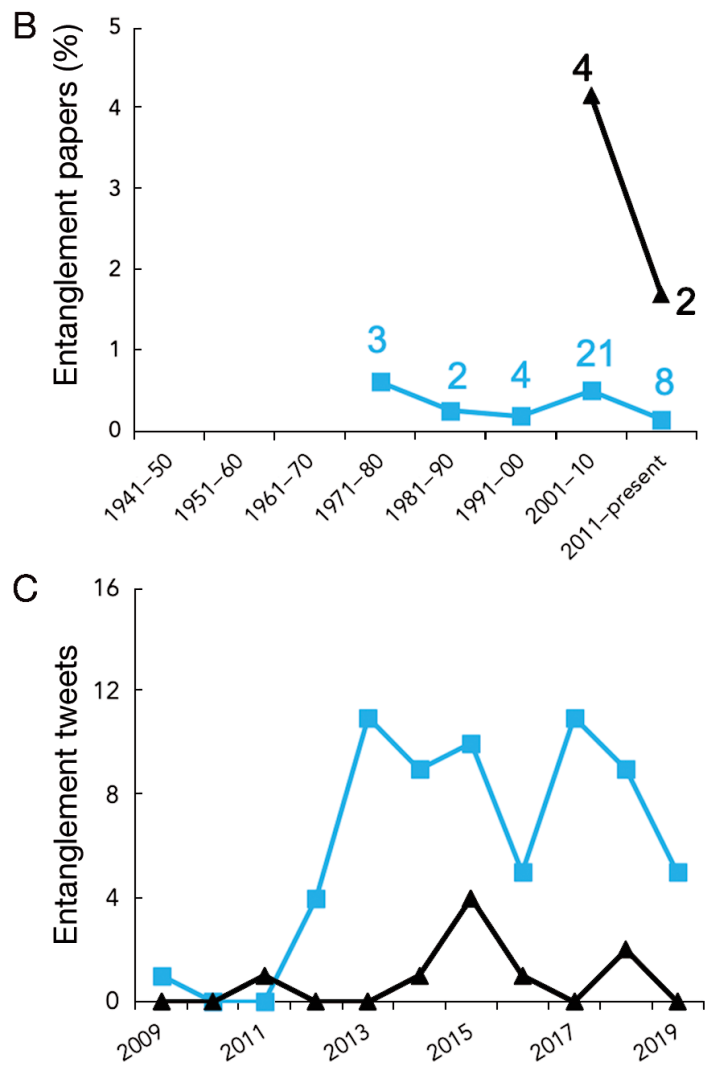

Fig. 1. Publication trends. (A) Total number of peer-reviewed articles on sharks (Galeomorphii and Squalomorphii) and rays (Batoidea) from 1941 to 2019. Based on Web of Science searches. (B) Entanglement papers as a percentage of total number of papers on sharks and rays, with numbers of publications annotated. (C) Total tweets featuring elasmobranch entanglement from the first recorded elasmobranch entanglement tweet in 2009 to 2019. Not shown: zero data points and chimaera papers (14 papers from 1981 to 2019, 2 featuring chimaera entanglement)

events of sharks, rays and chimaera, encompassing 34 different species $(82.9,12.7$ and $4.2 \%$, respectively) from 16 families, in 26 scientific publications between 1971 and 2019 (Table 1). The most affected species featuring in 3 or more publications were silky sharks Carcharhinus falciformis (12\%) and

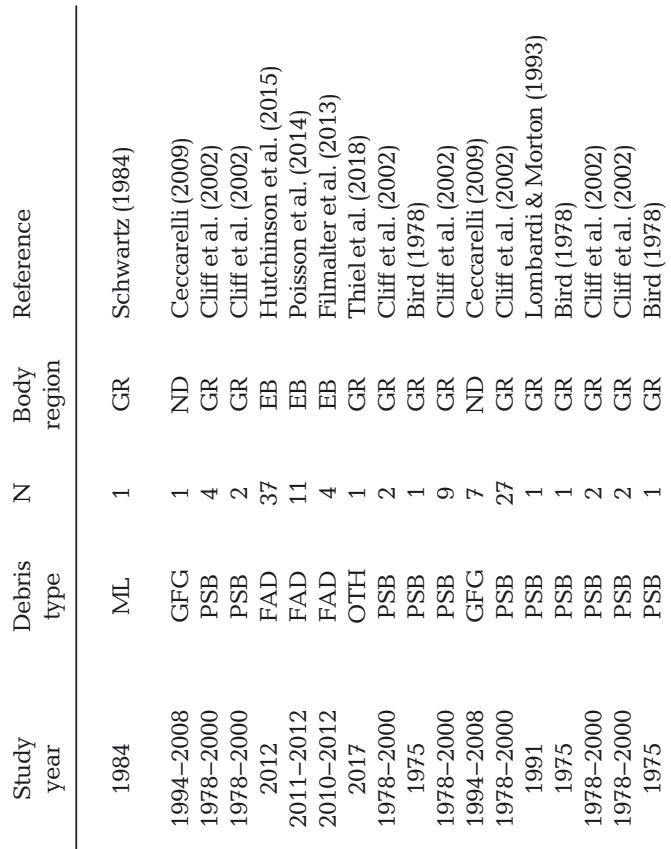

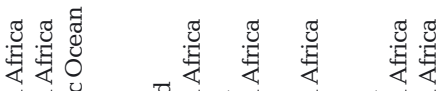

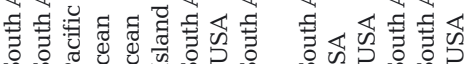

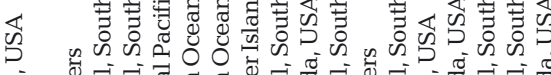

ฮ

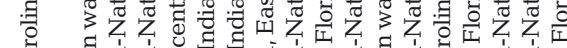

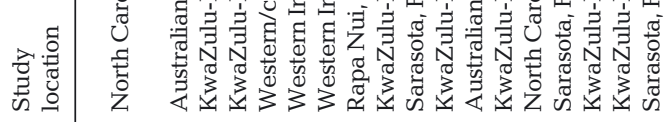

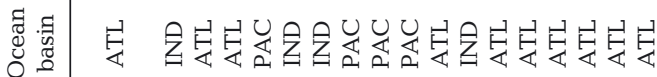

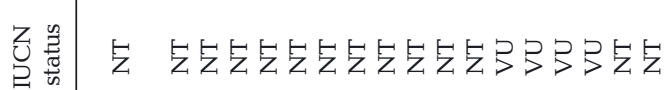

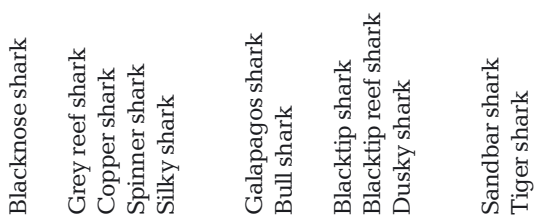

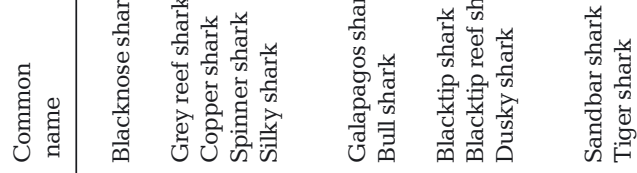

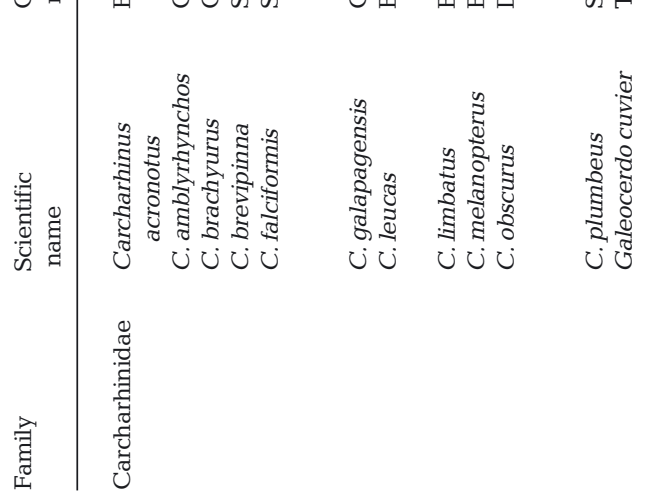




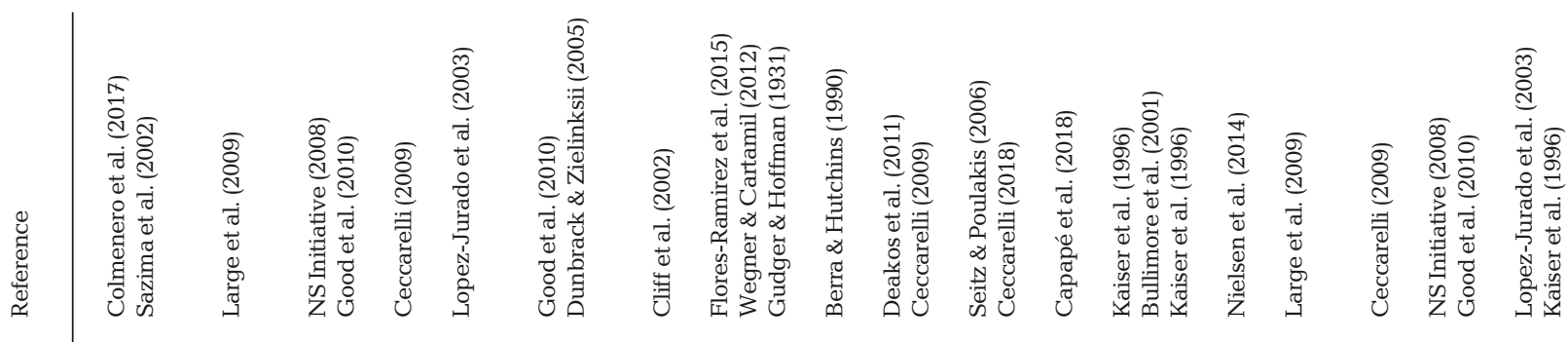

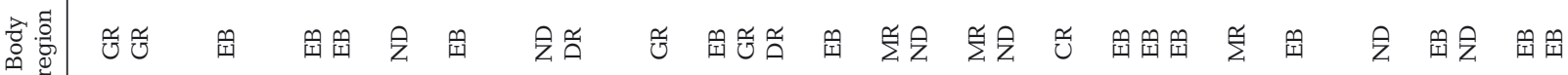

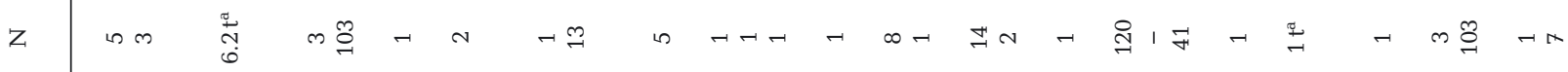

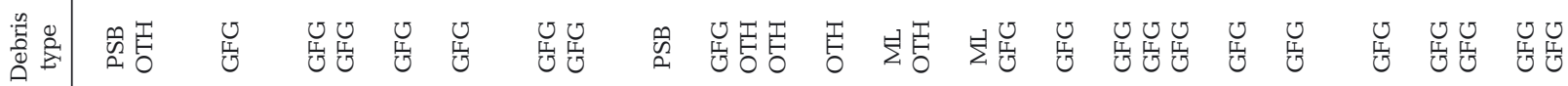

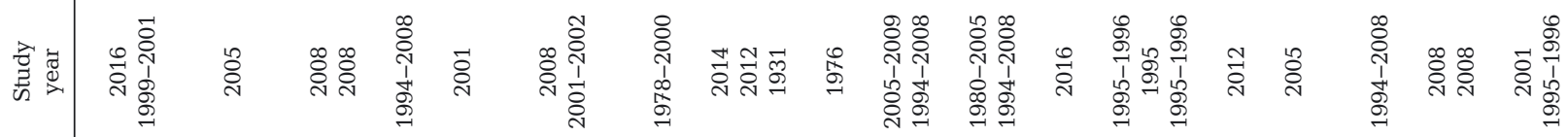

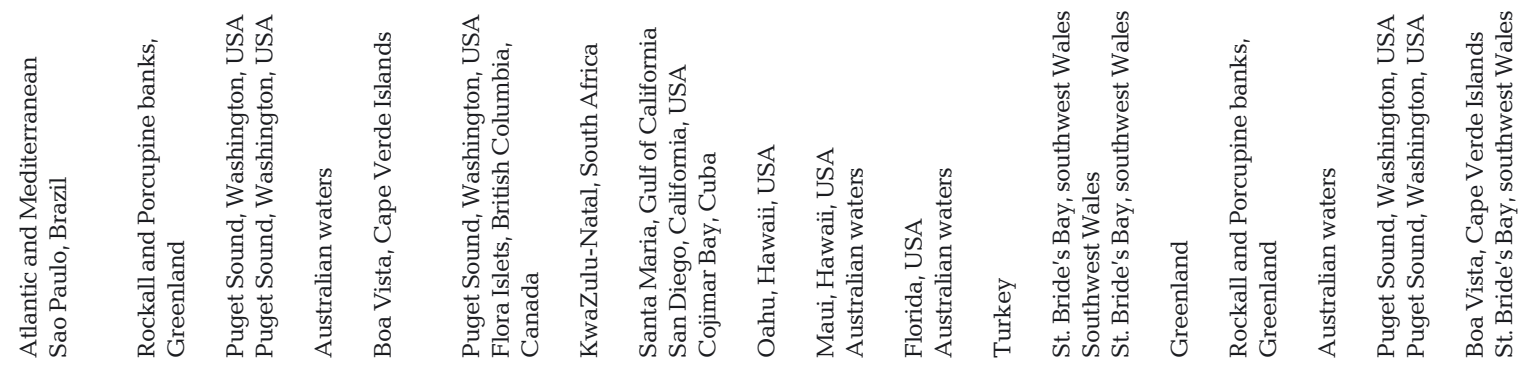

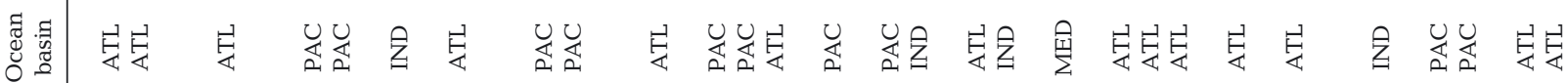

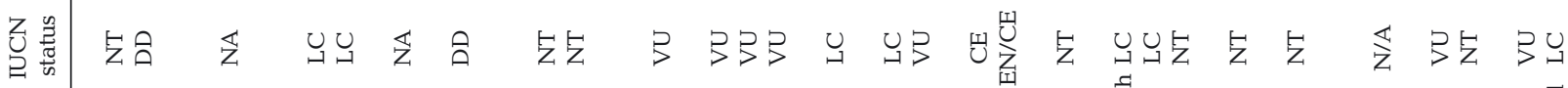

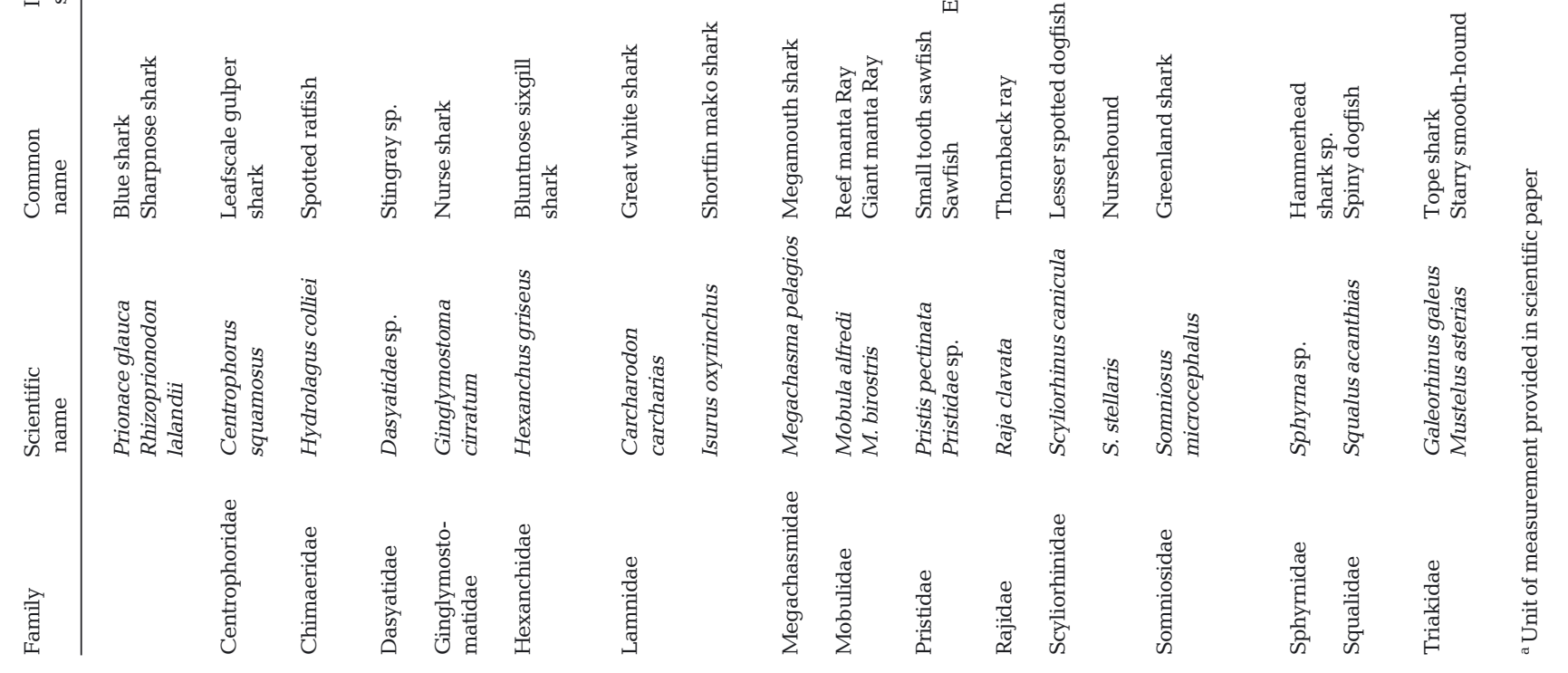


dusky sharks C. obscurus (12\%). Bull sharks C. leucas, bluntnose sixgill sharks Hexanchus griseus, great white sharks Carcharodon carcharias, Greenland sharks Somniosus microcephalus, lesser spotted dogfish Scyliorhinus canicula, shortfin mako sharks Isurus oxyrinchus, spiny dogfish Squalus acanthias and tiger sharks Galeocerdo cuvier featured in the top 10 entangled shark species, each comprising $8 \%$ of all entanglement records. A total of 557 animals were found to be entangled, with lesser spotted dogfish $(21.6 \%)$, spotted ratfish Hydrolagus colliei (19.1\%) and spiny dogfish $(19.1 \%)$ in the top 3 for most individuals entangled. Leafscale gulper shark Centrophorus squamosus and Greenland shark Somniosus microcephalus were reported as tonnes in their respective publications and therefore were omitted from this analysis.

On Twitter, although no incidences of chimaera entanglement were found, we recorded 74 different incidences of entangled sharks and rays, encompassing 26 species, between 2009 and 2019 (Fig. 1C, Table 2 ). The most reported species with 3 or more records of entanglement included whale sharks Rhincodon typus $(25.3 \%)$, great white sharks $(9.8 \%)$, lesser spotted dogfish (7\%), tiger sharks (5.6\%), basking sharks Cetorhinus maximus $(4.2 \%)$ and grey nurse sharks Carcharias taurus (4.2\%).

\subsection{Entangling materials}

Our review found that ghost fishing gear was responsible for over two-thirds of all the entanglement records in the published literature for sharks and rays $(74 \%$ of total animals, $N=412$ animals, Fig. 2A). Alongside this, $60 \%$ of total entangled animals had their entire body trapped $(\mathrm{N}=334$ animals), as more often than not when animals are entangled in ghost fishing gear, they become twisted in the material, trapping their entire bodies in the process. Four publications reported elasmobranchs entangled in polypropylene strapping bands (PSBs) (11\% of total animals, $\mathrm{N}=62$ animals). Our review also revealed that the gill region was a common area for sharks to become entangled (Fig. 2C), making up $12 \%$ of all entangled animals in the published literature ( $\mathrm{N}=68$ animals). Other landbased debris was reported in 6 publications $(1 \%$ of total animals, $\mathrm{N}=8$ animals), including circular plastic debris (see Fig. S1 in the Supplement at www.int-res.com/articles/suppl/n039p173_supp.pdf) which is commonly found on packs of canned beverages.
On Twitter, we again found ghost fishing gear was responsible for the majority of entanglement records (94.9\%, N = 531 animals, Fig. 2A). Other forms of debris, including polythene bags, elastic cords, clothing and SCUBA diving equipment, made up $3.4 \%$ of total entangled animals ( $\mathrm{N}=19$ animals). However, in 8 tweets (1.4\% of Twitter entanglement records), the item causing entanglement was not described.

\subsection{Geographic distribution}

Our review found records of elasmobranch entanglement in all but 2 of the world's oceans: the Arctic and Antarctic/Southern oceans, which have only a few reports of elasmobranch species (Long 1992, Campana et al. 2015). The majority of entangled animals in the published literature were found in the Pacific Ocean (49\%, N = 275 animals, Fig. 2B), with $46 \%(\mathrm{~N}=253$ animals $)$ and $5 \%(\mathrm{~N}=28$ animals $)$ of entangled animals originating from the Atlantic and Indian oceans, respectively. Areas where large populations of sharks that have been the subject of longterm scientific study appear to feature regularly, particularly in the USA ( $44 \%$ of animals, $\mathrm{N}=242$ ). The UK (30\% of animals, $N=168)$ and South Africa (10\% of animals, $N=53$ ) also feature numerous entanglement reports, albeit from single published papers. Other publications also originated from nations such as Canada and Australia (combined $4 \%$ of animals, $\mathrm{N}=26$, Fig. 3A).

The majority of entangled animals highlighted from Twitter originated from the Atlantic Ocean $(89.4 \%, N=500$ animals), with the Indian and Pacific oceans featuring significantly fewer reports of entanglement at $4.8 \%(\mathrm{~N}=27$ animals $)$ and $1.9 \%(\mathrm{~N}=11$ animals), respectively. A small proportion $(3.7 \%)$ of entanglement records were of unknown origin $(\mathrm{N}=21$ animals) (Fig. 3B).

\subsection{Families at risk}

Our review found 15 elasmobranch (and 1 chimaera) families were impacted by entanglement in anthropogenic debris based on the scientific literature (Table 1). From Twitter, we found 14 elasmobranch families were impacted. Combining the published literature with the results from Twitter, we identified 22 different families impacted: Alopiidae, Carcharhinidae, Centrophoridae, Cetorhinidae, Chimaeridae, Dasyatidae, Ginglymosomatidae, Heterodontidae, Hexanchidae, Lamnidae, Megachas- 
midae, Mobulidae, Odontaspididae, Orectolobidae, Pristidae, Rajidae, Rhincodontidae, Scyliorhinidae, Somniosidae, Sphyrnidae, Squalidae and Triakidae. The families more commonly impacted by entanglement are the houndsharks (Triakidae, 2 of 46 species, 467 individuals entangled), the catsharks (Scyliorhinidae, 2 of 148 species, 180 individuals), the requiem sharks (Carcharhinidae, 19 of 59 species, 143 individuals), the chimaeras (Chimaeridae, 1 of 38 species, 106 individuals), the dogfish sharks (Squalidae, 1 of 28 species, 106 individuals), the whale sharks (Rhincodontidae, 1 of 1 species, 21 individuals), the sawfish (Pristidae, 2 of 5 species, 17 individuals), the mobulas (Mobulidae, 2 of 8 species, 16 individuals), the cow sharks (Hexanchidae, 1 of 5 species, 14 individuals) and the mackerel/ white sharks (Lamnidae, 2 of 5 species, 13 individuals) (Fig. 4).

\section{DISCUSSION}

Entanglement in anthropogenic debris is symptomatic of a degraded marine environment. We find entanglement of sharks and rays is likely underreported in the scientific literature and identify it as a clear animal welfare issue. In conjunction with other threats to elasmobranchs, the issues surrounding entanglement within ghost fishing gear, if not mitigated, may contribute to population concerns for specific elasmobranch families across multiple ocean basins highlighted in Sections 4.1 and 4.3.

\subsection{Primary drivers of elasmobranch entanglement}

We believe the primary drivers for entanglement are habitat use, migratory species and body shape/ form.

The greatest number of entangled individuals stemmed from the houndsharks (Triakidae) and the catsharks (Scyliorhinidae). These families of sharks are demersal in nature, often feeding on crustaceans and small teleost fishes in benthic habitats up to 200-300 m (Ellis et al. 1996, Bengil et al. 2019). In our study, these species were generally entangled in large quantities of ghost fishing gear. Ghost gear when lost at sea can drift for long periods of time, until the weight of entangled species causes it to sink (Phillips 2017, Richardson et al. 2019). Once on the seabed, other scavenging marine species become entangled in the netting, consequently attracting predatory demer- sal elasmobranchs (Kaiser et al. 1996). The use of a demersal habitat may predispose these sharks to entanglement.

The carcharhinid sharks were one of the worst affected families, likely due to their high abundance, habitat use and mobile nature (Simpfendorfer \& Milward 1993), with many species travelling large distances (100s to 1000 s of kilometres) to feed, breed and give birth (Bonfil et al. 2005, Lea et al. 2015). Although not in the carcharhinid family of sharks, the same can be applied to whale sharks, basking sharks, white sharks and manta rays. Plastic pollution drifts passively across oceans worldwide (Barnes \& Milner 2005, Katsanevakis 2008, Wabnitz \& Nichols 2010, Eriksen et al. 2014); therefore, species that occupy these oceanic/pelagic habitats may be more likely to become entangled in debris through chance encounters. This could be particularly apparent if they congregate in convergence zones which aggregate large quantities of marine litter (Donohue et al. 2001, Martinez et al. 2009, Law et al. 2014)

The migratory pathways of multiple shark and ray species are now being mapped (Bonfil et al. 2005, Skomal et al. 2009, 2017, Block et al. 2011, Campana et al. 2011, Carlisle et al. 2012, Jaine et al. 2014, Thorrold et al. 2014, Werry et al. 2014, Braun et al. 2015, Braccini et al. 2016, Queiroz et al. 2016, Doherty et al. 2017, Omori \& Fisher 2017, Gaube et al. 2018). These pathways may overlap with large aggregations of debris, particularly for individuals displaying offshore migratory movements. This overlap is likely, as studies have recently highlighted crossover between filter-feeding megafauna habitat use and microplastic hotspots (Germanov et al. 2018). Sharks are also highly inquisitive in their nature (Laist 1997) and often bite objects to determine if they are palatable or not (Hammerschlag et al. 2012, West 2014). Carson (2013) noted $16 \%$ of plastic debris items beached in Hawaii showed bite marks from sharks or predatory fish, indicating testing of materials. Floating patches of plastic would undoubtedly be novel objects in a shark's environment, and this exploratory behaviour may often be the cause of initial entanglement in anthropogenic debris.

Species with specific body shapes and anatomically protruding appendages also appear to be prone to entanglement. Elasmobranchs that display an elongated body shape may be more prone to entanglement than those that are dorsoventrally flattened, due to their swimming kinematics and need for continuous forward motion (Lowe 1996, Lauder \& Di Santo 2015). This may explain the low number of rays found entangled across both the 
Table continued on next page

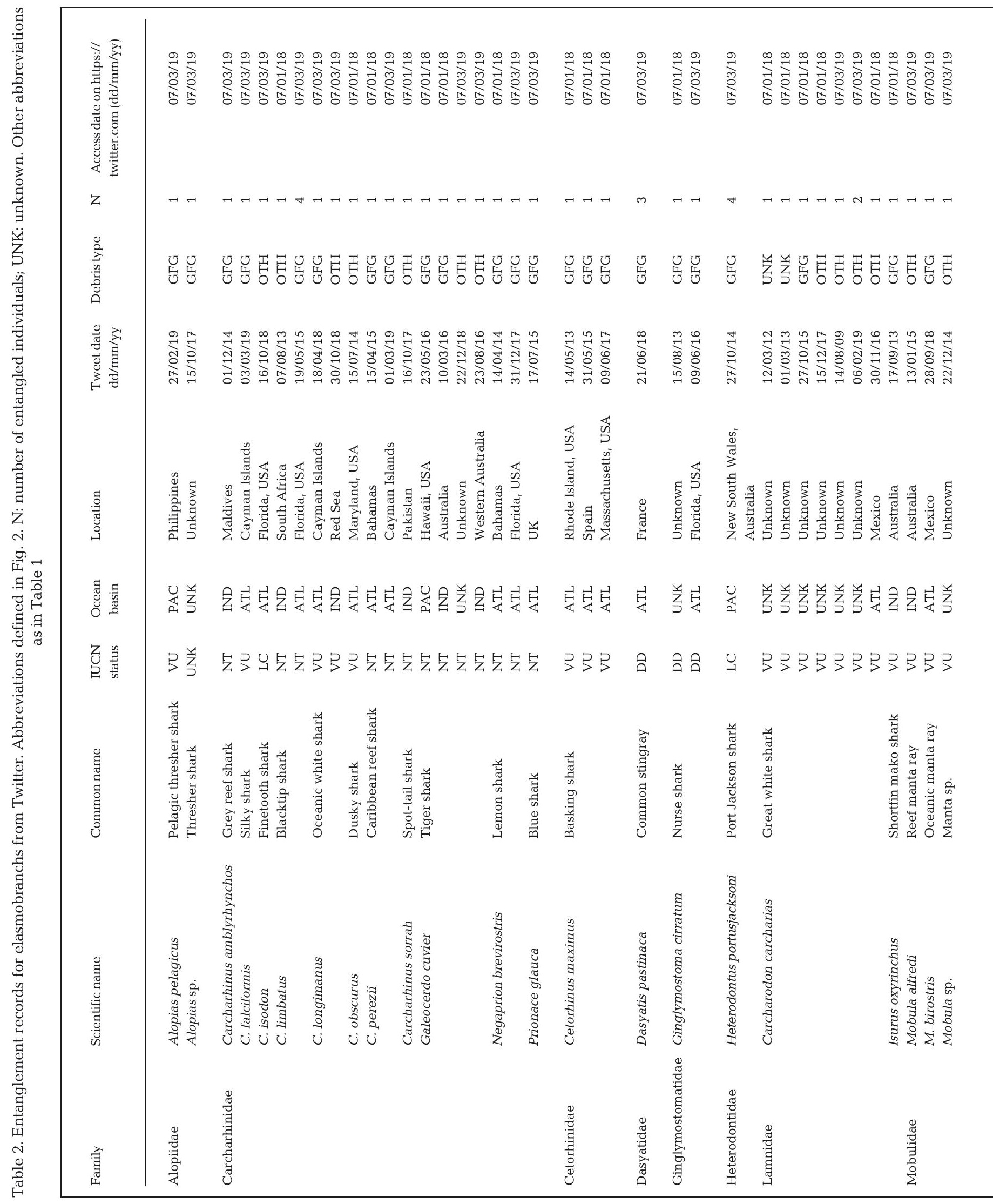




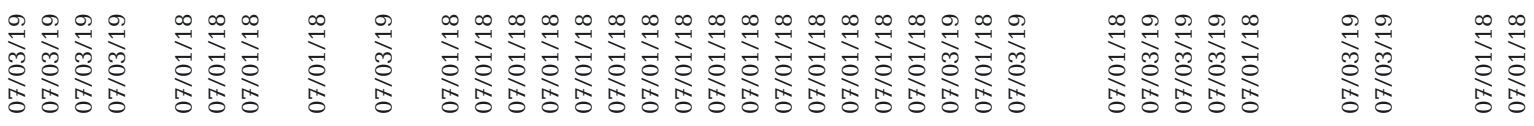

$\neg-r-$

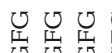

出出导 U U U

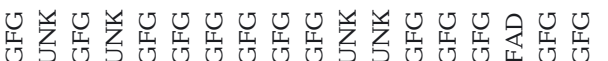

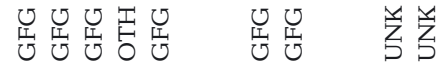

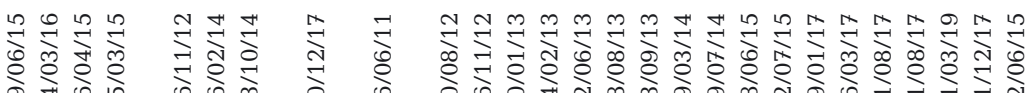

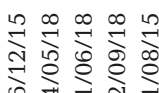

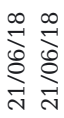

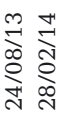

త్రే

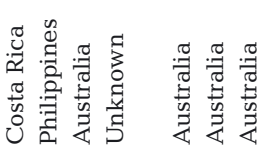

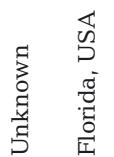

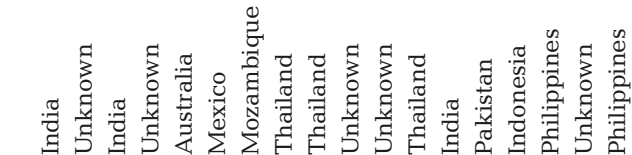

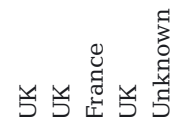

¿

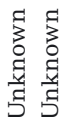

8

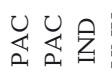

立立

旁

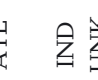

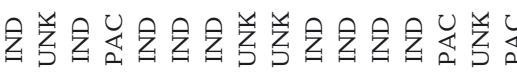

밥라불

是是总揱

๖.

333

333

学

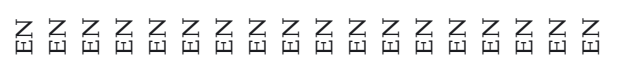

U.

B品尊

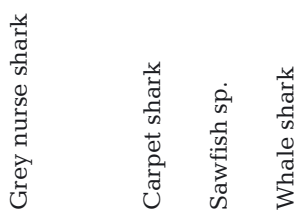

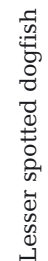
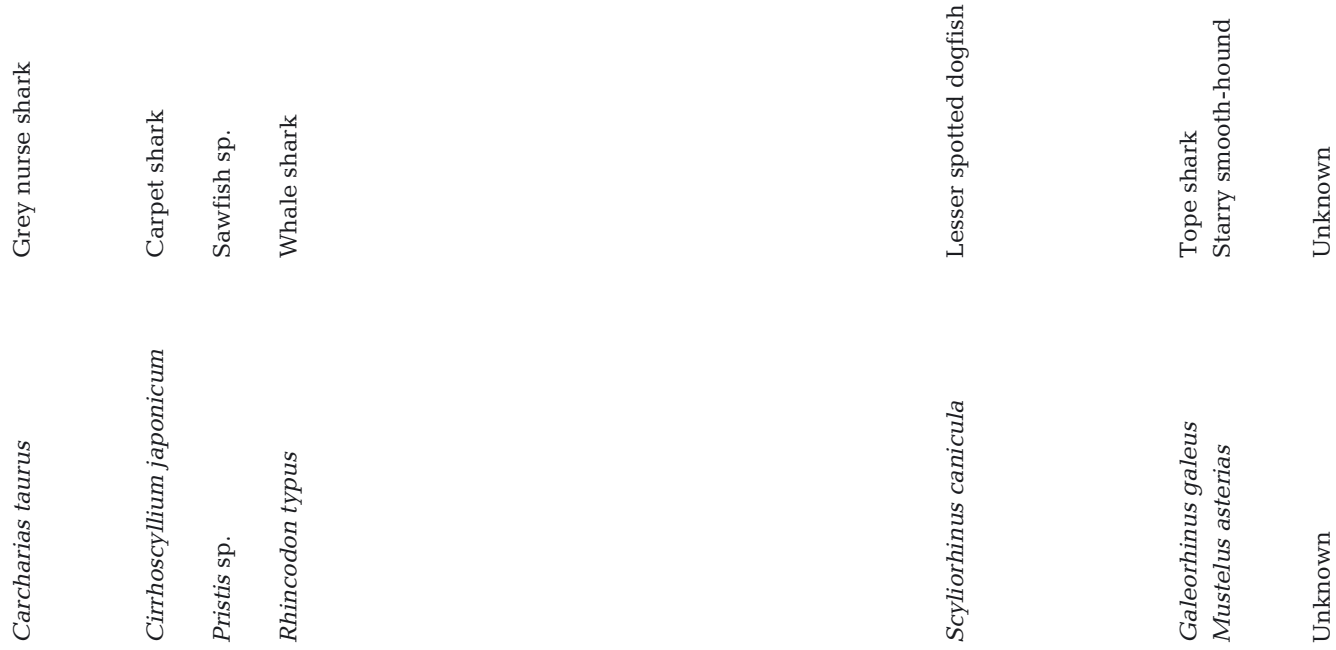

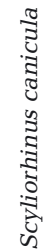

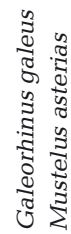

草

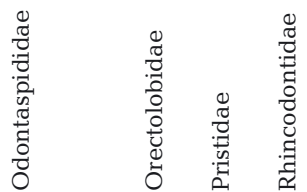

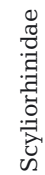

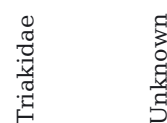



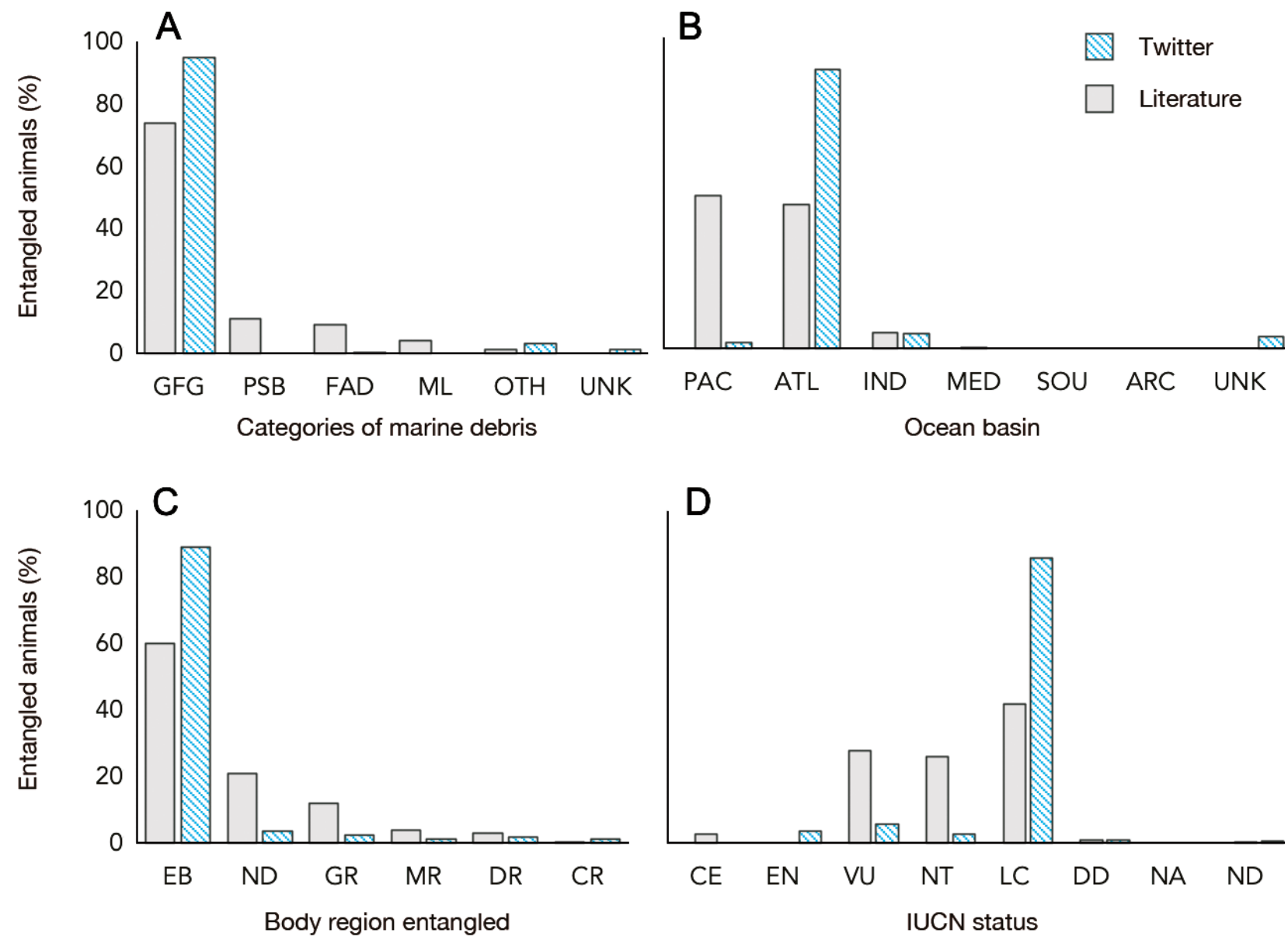

Fig. 2. Breakdown of published studies (grey) and Twitter reports (blue) as a percentage of total entangled animals. (A) Categories of marine debris (GFG: ghost fishing gear; PSB: polypropylene strapping band; FAD: fish aggregating device; ML: monofilament line; OTH: other; UNK: unknown). (B) Ocean basins (PAC: Pacific; ATL: Atlantic; IND: Indian; MED: Mediterranean; SOU: Southern; ARC: Arctic; UNK: unknown). Zero cases found in the Southern and Arctic oceans. (C) Region of the body entangled (EB: entire body; ND: no data; GR: gill region; MR: mouth region; DR: dorsal region; CR: caudal region). (D) IUCN status of species (CE: Critically Endangered; EN: Endangered; VU: Vulnerable; NT: Near Threatened; LC: Least Concern; DD: Data Deficient; NA: not assessed; ND: no data). Published studies: $\mathrm{n}=557$ animals, Twitter: $\mathrm{n}=559$ animals

scientific literature and Twitter. Other species with morphological differences, such as the basking shark's elongated snout and mobulid ray's cephalic fins, can easily become encircled or caught by marine debris such as monofilament line or PSBs (Stewart et al. 2018; Craig Whalley, https://www. youtube.com/watch? $\mathrm{v}=\mathrm{J}$-lPqciSNMI). Other species like the sawfishes (Pristidae) have elongated rostra lined with saw-like teeth which can also easily become entwined in monofilament fishing lines and netting. Although not primarily marine in nature, sawfish populations have declined at alarming rates in recent years (Jabado et al. 2017, Moore 2017, White et al. 2017, Leeney et al. 2018), mostly due to direct and indirect fishing pressures.
High habitat specificity, morphology and foraging strategies predispose them to entanglement in river and estuarine habitats, which are known to be major entrances of marine debris into oceans (Barnes et al. 2009, Rech et al. 2014, Smith \& Edgar 2014).

Despite our review being global in view, the relatively low numbers of incidences of entanglement are likely, at least in part, due to underreporting. This is evidenced by additional species and locations being highlighted on Twitter that were not featured in published reports. This could be due to the ease and instant nature of reporting such incidents via Twitter at the click of a button, often directly through a smartphone. Reports from the literature were often anecdotal; therefore, pro- 

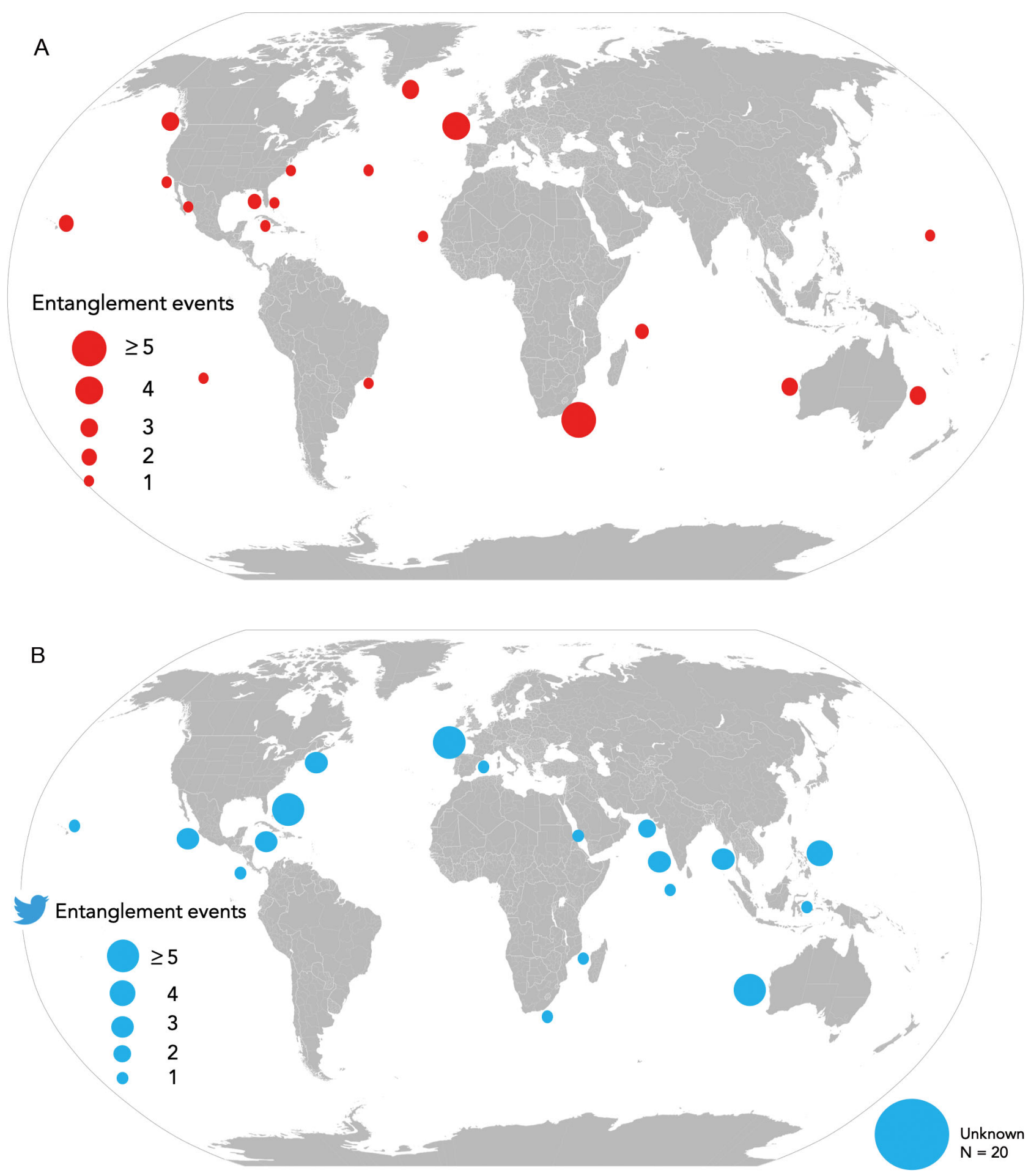

Fig. 3. Global distribution of entanglement events from (A) published scientific literature and (B) distinct tweets from Twitter from 2009 to 2019. Circles are proportional to magnitude

viding further in-depth information may not have been at the forefront of the authors' minds. Future efforts in the peer-reviewed literature should aim at providing as much information as possible when entangled elasmobranchs are encountered. Likewise, entanglement reports by members of the public via social media are inconsistent in nature and therefore could benefit from a citizen science platform 
via a website or smartphone app to aid in the collection, standardisation and organisation of data.

\subsection{Types of marine debris leading to entanglement}

\subsubsection{Ghost fishing gear}

Each year, approximately 6.4 million tonnes of fishing gear is lost in the world's oceans (Macfadyen et al. 2009, Wilcox et al. 2015). This ghost gear is a well-known threat to numerous marine taxa (Wilcox et al. 2013, Stelfox et al. 2016). Ghost fishing gear commonly consists of synthetic nylon nets that are non-biodegradable and can persist in the ocean for many years (Saldanha et al. 2003, Nelms et al. 2016). It is evident that ghost fishing presents a threat to elasmobranchs regarding entanglement, with the majority of animals identified from both the scientific literature and Twitter being entangled within ghost nets.

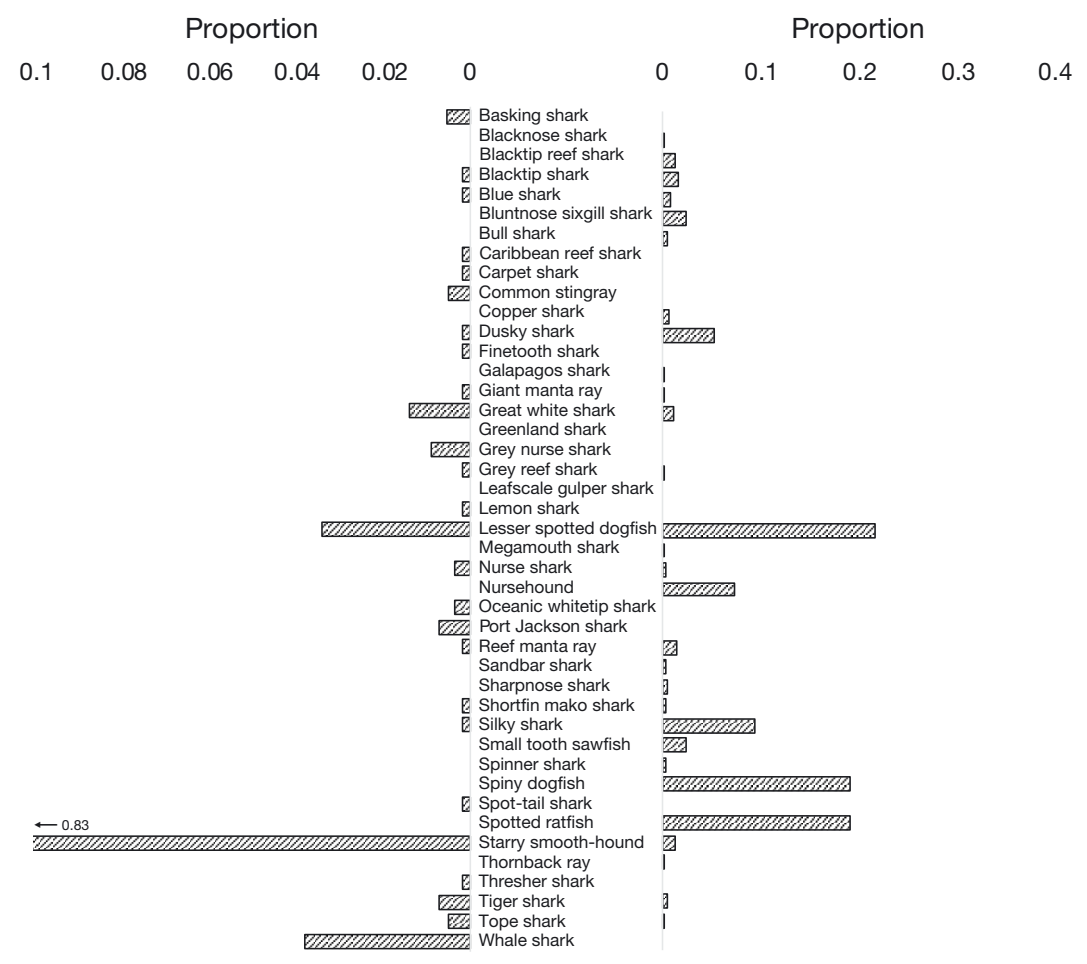

Fig. 4. Breakdown of entangled species by number of entangled sharks as a proportion of total entangled animals $(\mathrm{n}=544)$, as reported on Twitter (left) and number of entangled animals as a proportion of total individuals entangled, as given in the peer-reviewed literature $(n=552)$ (right). Unknown species removed. Greenland shark and leafscale gulper shark have no data points, as they were reported in the published paper in tonnes. Proportion for starry smooth-hound on Twitter annotated on figure

\subsubsection{FADs}

In our review, 3 publications (Filmalter et al. 2013, Poisson et al. 2014, Hutchinson et al. 2015) reported elasmobranchs becoming entangled in DFADs in the Indian Ocean. Within these studies, the silky shark was the only shark reported to have been entangled. The silky shark makes up $90 \%$ of the elasmobranch bycatch in the tuna purse seine fishery in the Indian Ocean (Gilman 2011), with estimates of between 480000 and 960000 individuals killed per year by FADs in this ocean (Filmalter et al. 2013). Of these individuals killed, large numbers are in the first 3 years of their life, indicating juveniles may be significantly impacted (Filmalter et al. 2013). The redesigning of FADs to minimise the use of large quantities of mesh netting is an emerging method in an attempt to reduce entanglement of shark species (Franco et al. 2009, Dagorn et al. 2013), as is the use of sisal ropes and biodegradable materials (Delgado de Molina et al. 2006, Franco et al. 2012, Filmalter et al. 2013).

One of the difficulties when reviewing publications concerning shark entanglement in DFADs is attempting to ascertain at which point in the process the shark became entangled. As stated in Section 2, some papers were omitted from this review, as we were unable to determine whether the sharks were passively entangled or caught as bycatch. Consequently, the numbers of elasmobranchs reported as entangled in DFADs is highly conservative and may, with clearer data collection, be the major source of entanglement in anthropogenic debris.

\subsubsection{Land-based debris}

PSBs made up 13 of the 19 landbased debris entanglement events in the scientific literature; these are commonly used in parcel packaging or with crates and pallets (Donaldson 1969). They are a rigid form of plastic that can often form a loop capable of encircling marine organisms, particularly around the gill region of sharks. This can have severe impacts on their ability to pass oxygen over the gills and can ultimately lead to suffocation 
(see Fig. S1). Naturally, it is difficult to ascertain the exact entry of PSBs into oceans, although possible entry points could include rivers, beaches or container ships transporting large boxed goods. Other land-based debris items entangling elasmobranchs included clothing, SCUBA equipment (regulator hose) and plastic packaging.

\subsection{Entanglement hotspots}

Plastic pollution has been found in all of the world's oceans, with many having their own plastic garbage patch (Eriksen et al. 2014). The most famous of these is located in the North Pacific gyre (Lebreton et al. 2018). Similar gyres can be found in the South Pacific as well as the North and South Atlantic (Eriksen et al. 2014). While the Pacific and Atlantic oceans contained the greatest numbers of entangled elasmobranchs across both the scientific literature and Twitter, we suggest more research is needed to ascertain high-risk ocean areas. Mapping debris hotspots alongside elasmobranch migration routes may provide further clarification on species that are expected to be severely impacted.

Although the Indian Ocean did not contain the highest numbers of entangled animals, it is known to suffer from heavy levels of plastic pollution, particularly in coastal areas (Jambeck et al. 2015), and is estimated to have more plastic than the South Atlantic and South Pacific combined (Eriksen et al. 2014). Paired with this problem, it is one of the most biodiverse oceans in the world for marine species, although data on elasmobranchs are somewhat lacking (Dulvy et al. 2008, Romanov et al. 2010, Tittensor et al. 2010, Wafar et al. 2011, Bowen et al. 2013). More research on this topic, alongside a greater understanding of entanglement in DFADs, could well reveal the Indian Ocean to be one of the major risk areas for elasmobranch entanglement.

There are several caveats associated with mapping the geographic locations of elasmobranch entanglement in the scientific literature as well as reports from Twitter. There is a known scientific sampling bias towards wealthier nations including the USA, Canada and the UK (May 1997, Momigliano \& Harcourt 2014). This may explain the large numbers of entanglement reports originating in the Atlantic Ocean, as wealthy countries have the resources to conduct more scientific research. There will also, undoubtedly, be more reports concentrated in areas where there are known elasmobranch populations that feature heavily in the sci- entific literature, including Australia, South Africa and Florida (Clark \& Von Schmidt 1965, Dudley \& Simpfendorfer 2006, Heithaus et al. 2007, Reid et al. 2011, Naylor et al. 2012).

\subsection{Social media}

The use of social media in acquiring data for the natural sciences is yet to be fully explored. Within 140 (and more recently 280) characters, we were usually able to ascertain the species, location and type of debris responsible for entanglement. We were aided by the occasional use of photographs uploaded alongside the tweet, or URL links provided within the tweet, to enable us to locate information that may not have been provided within the character limit. There were, however, several tweets where we were unable to garner all of the information required, the most notable being geographic location. Despite this, our searches highlighted 11 different elasmobranch species that had no records of entanglement in peerreviewed articles. Alarmingly, we found numerous tweets regarding whale shark entanglement, compared to none in the published literature. This emphasizes that entanglement is more than likely impacting a significantly greater number of species on a vastly larger scale than this review has presented.

In using social media as a tool to document the geographical locations of elasmobranch entanglement, it becomes difficult to control for factors such as tourists travelling to diving hotspots in tropically biodiverse coastal areas (Gössling 1999). This may explain the large numbers of entanglement records in the northern Indian Ocean and Indonesia. It is also difficult to control for biases towards more popular flagship species which are commonly encountered by members of the public in tourism hotspots; this again may explain the large number of distinct tweets featuring whale sharks and great white sharks.

Overall, the datasets found among social media sites can, at the least, be used to anecdotally document records of entanglement among elasmobranch species. We do not suggest the use of social media to be equivalent to that of a systematic literature review; however, by investigating the use of specific key words and hashtags on Twitter, scientists can obtain real-time data on entanglement events for a variety of marine species. To those working in the marine sector, or people who may encounter entangled elasmobranchs, it will be important to provide as much information as possible when deciding to post about these issues on social media. We recommend upload- 
ing photos of the entanglement if possible, whilst clearly stating the location, species entangled and the debris causing the entanglement. We also recommend using relevant hashtags such as \#Entanglement, \#Elasmobranch and \#MarineDebris to allow scientists to locate these posts quickly and efficiently. Social media remains a novel tool for identifying the threat of entanglement and can, if used correctly, provide valuable insights into marine conservation issues (Abreo et al. 2019).

\subsection{Future directions}

\subsubsection{Differentiation between entanglement and bycatch}

To ensure accurate reporting, it will be important to distinguish between entangled individuals and bycaught individuals. The low numbers reported in this review could indicate that entanglement incidents may have been included under the category of bycatch. Bycatch is well understood regarding threats to elasmobranchs and remains one of the most frequent threats to sharks globally, accounting for $66.9 \%$ of shark species reported by the IUCN (Molina \& Cooke 2012).

\subsubsection{Standardisation of data collection}

Our review found a distinct lack of standardisation in the reporting of entanglement of elasmobranchs in anthropogenic debris. Of the available scientific data in the literature, there is no standardisation in the reporting of entanglement incidents. Many incidents are only anecdotally available within studies, usually as an anecdote from a separate study (Bird 1978, Berra \& Hutchins 1990, Flores-Ramírez et al. 2015). There are examples in studies (Chanrachkij \& Loogon 2003, Ceccarelli 2009) listing ' $x$ ' number of 'sharks' or 'rays' as entangled; however, various data were missing on the species and, consequently, some of these accounts were not included in the review. A standardised method of reporting entanglement incidents would provide valuable scientific data in an attempt to qualitatively and quantitatively assess the entanglement of sharks and rays.

Due to this lack of data standardisation, it is also currently difficult to assess at what life stages elasmobranchs are most likely to become entangled. There are a handful of accounts of juvenile elasmobranchs being entangled in anthropogenic debris (Sazima et al. 2002, Colmenero et al. 2017). In most incidences, no information was available on life stage. Scientists have highlighted the importance of identifying vulnerable life stages of various marine taxa, with juvenile turtles, seals and whales commonly referred to as the most at risk from entanglement (Henderson 2001, Johnson et al. 2005, Mazaris et al. 2005, Duncan et al. 2017). If juvenile elasmobranch species are more susceptible to entanglement in marine anthropogenic debris, this could have important consequences for elasmobranch species at a population level due to lower recruitment rates, particularly for those species already threatened with extinction (Stevens et al. 2000). As a result, we recommend that when collecting data on entangled elasmobranchs, the following information should be included: species, size, sex, ontogenetic phase, number of individuals entangled, debris type causing entanglement and location of entanglement. With this information, it will be more likely that we will understand the extent of impact on sharks and rays worldwide.

Citizen science has grown rapidly in the last 2 decades, leading to an increase in its use in numerous peer-reviewed articles (Bonney et al. 2009, McKinley et al. 2017), and its impact on science cannot be ignored. Therefore, there is the potential for the creation of an online global database of elasmobranch entanglement, possibly run by a non-governmental organization, which allows for citizen scientists to upload information on entangled sharks and rays that they have encountered, thus enabling scientists to gather data quickly and efficiently. Alongside this, demographic studies in which rates of entanglement are calculated will aid scientists in implementing mitigation strategies for particularly threatened species of elasmobranchs or within problematic areas.

\section{CONCLUSIONS}

The numbers of entangled elasmobranchs reported here are minimal in comparison to the numbers of elasmobranchs caught directly in targeted fisheries or indirectly as bycatch. Nonetheless, there is no doubt that entanglement in anthropogenic debris is an additional threat to sharks and rays. Further research may reveal this threat to be simply an animal welfare issue rather than having wide-ranging population-level effects that have conservation implications. It is apparent, however, that entanglement in anthropogenic debris from land-based pollution and discarded fishing gear is a severely underreported threat to sharks, and further research will help fill in existing knowledge gaps. The scientific community should work together 
with the fisheries sector and the general public in an attempt to better quantify and understand this threat. Mitigating strategies that target the issues of ghost fishing, land-based pollution and problematic areas within oceans may aid in reducing the risks for declining elasmobranch species.

Acknowledgements. The authors extend their thanks to the editor and 3 anonymous reviewers who gave constructive feedback, which has greatly improved the manuscript. This work was undertaken with approval of the University of Exeter Animal Ethics Committee.

\section{LITERATURE CITED}

Abreo NAS, Thompson KF, Arabejo GFP, Superio MDA (2019) Social media as a novel source of data on the impact of marine litter on megafauna: the Philippines as a case study. Mar Pollut Bull 140:51-59

Adams PB (1980) Life history patterns in marine fishes and their consequences for fisheries management. Fish Bull 78:1-12

Barnes DKA, Milner P (2005) Drifting plastic and its consequences for sessile organism dispersal in the Atlantic Ocean. Mar Biol 146:815-825

Barnes DKA, Galgani F, Thompson RC, Barlaz M (2009) Accumulation and fragmentation of plastic debris in global environments. Philos Trans R Soc B 364:1985-1998

Barreiros JP, Raykov VS (2014) Lethal lesions and amputation caused by plastic debris and fishing gear on the loggerhead turtle Caretta caretta (Linnaeus, 1758). Three case reports from Terceira Island, Azores (NE Atlantic). Mar Pollut Bull 86:518-522

Bengil F, Bengil EGT, Mavruk S, Heral O, Karaman OD, Ozaydin O (2019) Feeding ecology of four demersal shark species (Etmopterus spinax, Galeus melastomus, Scyliorhinus canicula and Squalus blainville) from the eastern Aegean sea. Turk J Fish Aquat Sci 19:475-484

Berra TM, Hutchins JB (1990) A specimen of megamouth shark, Megachasma pelagios (Megachasmidae) from Western Australia. Rec West Aust Mus 14:651-656

Bird PM (1978) Tissue regeneration in three carcharhinid sharks encircled by embedded straps. Copeia 1978: 345-349

Block BA, Jonsen ID, Jorgensen SJ, Winship AJ and others (2011) Tracking apex marine predator movements in a dynamic ocean. Nature 475:86-90

Bond T, Ferrandiz-Mas V, Felipe-Sotelo M, van Sebille E (2018) The occurrence and degradation of aquatic plastic litter based on polymer physicochemical properties: a review. Crit Rev Environ Sci Technol 48:685-722

Bonfil R, Meÿer M, Scholl MC, Johnson R and others (2005) Transoceanic migration, spatial dynamics, and population linkages of white sharks. Science 310:100-103

* Bonney R, Cooper CB, Dickinson J, Kelling S, Phillips T, Rosenberg KV, Shirk J (2009) Citizen science: a developing tool for expanding science knowledge and scientific literacy. Bioscience 59:977-984

Bowen BW, Rocha LA, Toonen RJ, Karl SA and others (2013) The origins of tropical marine biodiversity. Trends Ecol Evol 28:359-366

Braccini M, Aires-da-Silva A, Taylor I (2016) Incorporating movement in the modelling of shark and ray population dynamics: approaches and management implications.
Rev Fish Biol Fish 26:13-24

* Braun CD, Skomal GB, Thorrold SR, Berumen ML (2015) Movements of the reef manta ray (Manta alfredi) in the Red Sea using satellite and acoustic telemetry. Mar Biol 162:2351-2362

Bullimore BA, Newman PB, Kaiser MJ, Gilbert SE Lock KM (2001) A study of catches in a fleet of "ghost-fishing" pots. Fish Bull 99:247-247

Cailliet GM, Andrews AH, Burton EJ, Watters DL, Kline DE, Ferry-Graham LA (2001) Age determination and validation studies of marine fishes: Do deep-dwellers live longer? Exp Gerontol 36:739-764

* Campana SE, Dorey A, Fowler M, Joyce W, Wang Z, Wright D, Yashayaev I (2011) Migration pathways, behavioural thermoregulation and overwintering grounds of blue sharks in the northwest Atlantic. PLOS ONE 6: e16854

Campana SE, Fisk AT, Klimley AP (2015) Movements of Arctic and northwest Atlantic Greenland sharks (Somniosus microcephalus) monitored with archival satellite pop-up tags suggest long-range migrations. Deep Sea Res II 115:109-115

Capapé C, Aydin I, Akyol O (2018) Morphological deformities and atypical colour pattern in thornback ray, Raja clavata (Elasmobranchii: Rajiformes: Rajidae), from Izmir (Turkey, Aegean Sea, Eastern Mediterranean). Acta Ichthyol Piscat 48:261-266

Carlisle AB, Kim SL, Semmens BX, Madigan DJ and others (2012) Using stable isotope analysis to understand the migration and trophic ecology of northeastern Pacific white sharks (Carcharodon carcharias). PLOS ONE 7: e30492

Carson HS (2013) The incidence of plastic ingestion by fishes: from the prey's perspective. Mar Poll Bull 74: 170-174

Ceccarelli DM (2009) Impacts of plastic debris on Australian marine wildlife. Department of the Environment, Water, Heritage and the Arts, Canberra

Chanrachkij I, Loog-on A (2003) Preliminary report on ghost fishing phenomena by drifting FADs in eastern Indian Ocean. Report TD/RES/78. Southeast Asian Fisheries Development Center, Samutoraka

Clark E, Von Schmidt K (1965) Sharks of the central Gulf coast of Florida. Bull Mar Sci 15:13-83

Cliff G, Dudley SFJ, Ryan PG, Singletonc N (2002) Large sharks and plastic debris in KwaZulu-Natal, South Africa. Mar Freshw Res 53:575-581

Cole M, Lindeque P, Halsband C, Galloway TS (2011) Microplastics as contaminants in the marine environment: a review. Mar Pollut Bull 62:2588-2597

Colmenero AI, Barria C, Broglio E, Garcia-Barcelona S (2017) Plastic debris straps on threatened blue shark Prionace glauca. Mar Pollut Bull 115:436-438

*Dagorn L, Holland KN, Restrepo V, Moreno G (2013) Is it good or bad to fish with FADs? What are the real impacts of the use of drifting FADs on pelagic marine ecosystems? Fish Fish 14:391-415

Navies RWD, Cripps SJ, Nickson A, Porter G (2009) Defining and estimating global marine fisheries bycatch. Mar Policy 33:661-672

* Davies TK, Stevens G, Meekan MG, Struve J, Rowcliffe JM (2012) Can citizen science monitor whale-shark aggregations? Investigating bias in mark-recapture modelling using identification photographs sourced from the public. Wildl Res 39:696-704

Deakos MH, Baker JD, Bejder L (2011) Characteristics of a manta ray Manta alfredi population off Maui, Hawaii, 
and implications for management. Mar Ecol Prog Ser 429:245-260

Delgado de Molina A, Ariz J, Santana JC, Déniz S (2006) Study of alternative models of artificial floating objects for tuna fishery (experimental purse-seine campaign in the Indian Ocean). IOTC-2006-WPBy-05

Derraik JGB (2002) The pollution of the marine environment by plastic debris: a review. Mar Pollut Bull 44: 842-852

Doherty PD, Baxter JM, Gell FR, Godley BJ and others (2017) Long-term satellite tracking reveals variable seasonal migration strategies of basking sharks in the north-east Atlantic. Sci Rep 7:42837

Donaldson (1969) Reinforced plastic strapping laminate Filed July 21, 19643 Sheets-Sheet 1 Inventor (f/H56 DOA/A40 50 101ml, M, MZFK- MLVM ATTORNEY5 Oct. 28, 1969 c. Donaldson 3,475,264. https://patents. google.com/patent/US3475264A/en

Donohue MJ, Boland RC, Sramek CM, Antonelis GA (2001) Derelict fishing gear in the northwestern Hawaiian Islands: diving surveys and debris removal in 1999 confirm threat to coral reef ecosystems. Mar Pollut Bull 42: 1301-1312

* Dudley SFJ, Simpfendorfer CA (2006) Population status of 14 shark species caught in the protective gillnets off KwaZulu-Natal beaches, South Africa, 1978-2003. Mar Freshw Res 57:225

Dulvy NK, Baum JK, Clarke S, Compagno LJV and others (2008) You can swim but you can't hide: the global status and conservation of oceanic pelagic sharks and rays. Aquat Conserv 18: 459-482

Dulvy NK, Fowler SL, Musick JA, Cavanagh RD and others (2014) Extinction risk and conservation of the world's sharks and rays. elife 3:e00590

Dunbrack R, Zielinski R (2005) Body size distribution and frequency of anthropogenic injuries of bluntnose sixgill sharks, Hexanchus griseus, at Flora Islets, British Columbia. Can Field Nat 119:537-540

Duncan EM, Botterell ZLR, Broderick AC, Galloway TS, Lindeque PK, Nuno A, Godley BJ (2017) A global review of marine turtle entanglement in anthropogenic debris: a baseline for further action. Endang Species Res 34: 431-448

Ellis JR, Pawson MG, Shackley SE (1996) The comparative feeding ecology of six species of shark and four species of ray (Elasmobranchii) in the north-east Atlantic. J Mar Biol Assoc UK 76:89

Eriksen M, Lebreton LCM, Carson HS, Thiel M and others (2014) Plastic pollution in the world's oceans: more than 5 trillion plastic pieces weighing over 250,000 tons afloat at sea. PLOS ONE 9:e111913

Filmalter JD, Capello M, Deneubourg JL, Cowley PD, Dagorn L (2013) Looking behind the curtain: quantifying massive shark mortality in fish aggregating devices. Front Ecol Environ 11:291-296

Fischer V, Elsner NO, Brenke N, Schwabe E (2015) Plastic pollution of the Kuril-Kamchatka Trench area (NW Pacific). Deep Sea Res II 111:399-405

Flores-Ramírez S, López-Fuerte FO, Reyes-Bonilla H, JakesCota U, Aquino-Baleytó M (2015) An injured specimen of Carcharodon carcharias; prospective assessment of the species' hunting costs. CICIMAR Oceánides 30:55-59

Fonteneau A, Pallarés P, Pianet R (2000) A worldwide review of purse seine fisheries on FADs. In: Le Gall JY, Cayré $P$, Taquet $M$ (eds) Pêche thonière et dispositifs de concentration de poissons. Actes Colloques-IFREMER 28:15-35
Fossi MC, Coppola D, Baini M, Giannetti M and others (2014) Large filter feeding marine organisms as indicators of microplastic in the pelagic environment: the case studies of the Mediterranean basking shark (Cetorhinus maximus) and fin whale (Balaenoptera physalus). Mar Environ Res 100:17-24

Fossi MC, Baini M, Panti C, Galli M and others (2017) Are whale sharks exposed to persistent organic pollutants and plastic pollution in the Gulf of California (Mexico)? First ecotoxicological investigation using skin biopsies. Comp Biochem Physiol C 199:48-58

Franco J, Dagorn L, Sancristobal I, Moreno G (2009) Design of ecological FADs. IOTC-2008-WPEB-16

Franco J, Moreno G, López J, Sancristobal I (2012) Testing new designs of drifting fish aggregating device (DFAD) in the eastern Atlantic to reduce turtle and shark mortality. IOTC-2009-WPEB-16

Galgani F, Hanke G, Maes T (2015) Global distribution, composition and abundance of marine litter. In: Bergmann M, Gutow L, Klages M (eds) Marine anthropogenic litter. Springer, Cham, p 29-56

* Gall SC, Thompson RC (2015) The impact of debris on marine life. Mar Pollut Bull 92:170-179

*Gaube P, Braun CD, Lawson GL, McGillicuddy DJ and others (2018) Mesoscale eddies influence the movements of mature female white sharks in the Gulf Stream and Sargasso Sea. Sci Rep 8:7363

Germanov ES, Marshall AD, Bejder L, Fossi MC, Loneragan NR (2018) Microplastics: no small problem for filter-feeding megafauna. Trends Ecol Evol 33:227-232

*Gilman EL (2011) Bycatch governance and best practice mitigation technology in global tuna fisheries. Mar Policy 35:590-609

Gilman E (2015) Status of international monitoring and management of abandoned, lost and discarded fishing gear and ghost fishing. Mar Policy 60:225-239

Good TP, June JA, Etnier MA, Broadhurst G (2010) Derelict fishing nets in Puget Sound and the Northwest Straits: patterns and threats to marine fauna. Mar Pollut Bull 60:39-50

Gössling S (1999) Ecotourism: a means to safeguard biodiversity and ecosystem functions? Ecol Econ 29:303-320

Gregory MR (1996) Plastic 'scrubbers' in hand cleansers: a further (and minor) source for marine pollution identified. Mar Pollut Bull 32:867-871

Gregory MR, Ryan PG (1997) Pelagic plastics and other seaborne persistent synthetic debris: a review of Southern Hemisphere perspectives. In: Coe JM, Rogers DB (eds) Marine debris: sources, impacts, and solutions. Springer-Verlag, New York, NY, p 49-66

Gudger EW, Hoffmann WH (1931) A shark encircled with a rubber automobile tire. Sci Mon 46:281-285

*Hammerschlag N, Gallagher AJ, Wester J, Luo J, Ault JS (2012) Don't bite the hand that feeds: assessing ecological impacts of provisioning ecotourism on an apex marine predator. Funct Ecol 26:567-576

*Heithaus MR, Burkholder D, Hueter RE, Heithaus LI, Pratt HL Jr, Carrier JC (2007) Spatial and temporal variation in shark communities of the lower Florida Keys and evidence for historical population declines. Can J Fish Aquat Sci 64:1302-1313

*Henderson JR (2001) A pre- and post-MARPOL Annex V summary of Hawaiian monk seal entanglements and marine debris accumulation in the northwestern Hawaiian Islands, 1982-1998. Mar Pollut Bull 42:584-589

Heppell SS, Crowder LB, Crouse DT (1996) Models to evaluate headstarting as a management tool for long-lived 
turtles. Ecol Appl 6:556-565

Hutchinson MR, Itano DG, Muir JA, Holland KN (2015) Postrelease survival of juvenile silky sharks captured in a tropical tuna purse seine fishery. Mar Ecol Prog Ser 521: 143-154

Jabado RW, Al Baharna RA, Al Ali SR, Al Suwaidi KO, Al Blooshi AY, Al Dhaheri SS (2017) Is this the last stand of the Critically Endangered green sawfish Pristis zijsron in the Arabian Gulf? Endang Species Res 32:265-275

Jaine FRA, Rohner CA, Weeks SJ, Couturier LIE, Bennett MB, Townsend KA, Richardson AJ (2014) Movements and habitat use of reef manta rays off eastern Australia: offshore excursions, deep diving and eddy affinity revealed by satellite telemetry. Mar Ecol Prog Ser 510:73-86

Jambeck JR, Geyer R, Wilcox C, Siegler TR and others (2015) Plastic waste inputs from land into the ocean. Science 347:768-771

Johnson A, Salvador G, Kenney J, Robbins J, Kraus S, Landry S, Clapham P (2005) Fishing gear involved in entanglements of right and humpback whales. Mar Mamm Sci 21:635-645

Kaiser MJ, Bullimore B, Newman P, Lock K, Gilbert S (1996) Catches in 'ghost fishing' set nets. Mar Ecol Prog Ser 145: 11-16

Katsanevakis S (2008) Marine debris, a growing problem: sources, distribution, composition, and impacts. In: Hofer TN (ed) Marine pollution: new research. Nova Science Publishers, New York, NY, p 53-100

Laist DW (1997) Impacts of marine debris: entanglement of marine life in marine debris including a comprehensive list of species with entanglement and ingestion records. In: Coe JM, Rogers DB (eds) Marine debris: sources, impacts, and solutions. Springer-Verlag, New York, NY, p 99-139

Large PA, Graham NG, Hareide NR, Misund R and others (2009) Lost and abandoned nets in deep-water gillnet fisheries in the Northeast Atlantic: retrieval exercises and outcomes. ICES J Mar Sci 66:323-333

Lauder GV, Di Santo V (2015) Swimming mechanics and energetics of elasmobranch fishes. Fish Physiol 34: 219-253

Law KL, Morét-Ferguson SE, Goodwin DS, Zettler ER, Deforce E, Kukulka T, Proskurowski G (2014) Distribution of surface plastic debris in the eastern Pacific Ocean from an 11-year data set. Environ Sci Technol 48: $4732-4738$

Lawson TJ, Wilcox C, Johns K, Dann P, Hardesty BD (2015) Characteristics of marine debris that entangle Australian fur seals (Arctocephalus pusillus doriferus) in southern Australia. Mar Pollut Bull 98:354-357

Lea JSE, Humphries NE, Clarke CR, Sims DW (2015) To Madagascar and back: long-distance, return migration across open ocean by a pregnant female bull shark. J Fish Biol 87:1313-1321

Lebreton L, Slat B, Ferrari F, Sainte-Rose B and others (2018) Evidence that the Great Pacific Garbage Patch is rapidly accumulating plastic. Sci Rep 8:4666

Leeney RH, Mana RR, Dulvy NK (2018) Fishers' ecological knowledge of sawfishes in the Sepik and Ramu rivers, northern Papua New Guinea. Endang Species Res 36: $15-26$

Lombardi J, Morton M (1993) Dusky shark injured by plastic packing strap encirclement off North Carolina. J Elisha Mitchell Sci Soc 109:180-182

Long DJ (1992) Paleoecology of Eocene Antarctic sharks. Antarct Res Ser 56:131-139

López-Jurado LF, Varo-Cruz N, López P (2003) Incidental capture of loggerhead turtles (Caretta caretta) on Boa
Vista (Cape Verde Islands). Mar Turtle Newsl 101:14-16

Lowe C (1996) Kinematics and critical swimming speed of juvenile scalloped hammerhead sharks. J Exp Biol 199: 2605-2610

Macfadyen G, Huntington T, Cappell R (2009) Abandoned, lost or otherwise discarded fishing gear. UNEP Reg Seas Rep Stud No. 185, FAO Fish Aquacult Tech Pap No. 523. UNEP/FAO, Rome

*Martinez E, Maamaatuaiahutapu K, Taillandier V (2009) Floating marine debris surface drift: convergence and accumulation toward the South Pacific subtropical gyre. Mar Pollut Bull 58:1347-1355

* Maufroy A, Chassot E, Joo R, Kaplan DM (2015) Large-scale examination of spatio-temporal patterns of drifting fish aggregating devices (dFADs) from tropical tuna fisheries of the Indian and Atlantic oceans. PLOS ONE 10:e0128023

May RM (1997) The scientific wealth of nations. Science 275: 793-796

* Mazaris AD, Fiksen Ø, Matsinos YG (2005) Using an individual-based model for assessment of sea turtle population viability. Popul Ecol 47:179-191

*McKinley DC, Stepenuck KF, Chapin SF, Wiggins A and others (2017) Citizen science can improve conservation science, natural resource management, and environmental protection. Biol Conserv 208:15-28

Ménard F, Stéquert B, Rubin A, Herrera M, Marchal É (2000) Food consumption of tuna in the equatorial Atlantic Ocean: FAD-associated versus unassociated schools. Aquat Living Resour 13:233-240

* Molina J, Cooke S (2012) Trends in shark bycatch research: current status and research needs. Rev Fish Biol Fish 22:719-737

Momigliano P, Harcourt R (2014) Shark conservation, governance and management: the science-law disconnect. In: Techera EJ, Klein N (eds) Sharks: conservation, governance and management. Routledge, London, p 89-106

Moore ABM (2017) Are guitarfishes the next sawfishes? Extinction risk and an urgent call for conservation action. Endang Species Res 34:75-88

*Naylor GJP, Caira JN, Jensen K, Rosana KAM, White WT, Last PR (2012) A DNA sequence-based approach to the identification of shark and ray species and its implications for global elasmobranch diversity and parasitology. Bull Am Mus Nat Hist No. 367

*Nelms SE, Duncan EM, Broderick AC, Galloway TS and others (2016) Plastic and marine turtles: a review and call for research. ICES J Mar Sci 73:165-181

* Nelms SE, Galloway TS, Godley BJ, Jarvis DS, Lindeque PK (2018) Investigating microplastic trophic transfer in marine top predators. Environ Pollut 238:999-1007

Nielsen J, Hedeholm RB, Simon M, Steffensen JF (2014) Distribution and feeding ecology of the Greenland shark (Somniosus microcephalus) in Greenland waters. Polar Biol 37:37-46

NS Initiative (Northwest Straits Initiative) (2008) Rates of marine species mortality caused by derelict fishing nets in Puget Sound, Washington. Northwest Straits Foundation, Bellingham, WA. https://nwstraitsfoundation.org/ download/rates-of-marine-species-mortality-caused-byderelict-fishing-nets-in-puget-sound-washington/

Omori KL, Fisher RA (2017) Summer and fall movement of cownose ray, Rhinoptera bonasus, along the east coast of United States observed with pop-up satellite tags. Environ Biol Fishes 100:1435-1449

*Page B, McKenzie J, McIntosh R, Baylis A and others (2004) Entanglement of Australian sea lions and New Zealand fur seals in lost fishing gear and other marine debris 
before and after government and industry attempts to reduce the problem. Mar Pollut Bull 49:33-42

Pardini AT, Jones CS, Noble LR, Kreiser B and others (2001) Sex-biased dispersal of great white sharks. Nature 412:139-140

* Pearson RG, Stanton JC, Shoemaker KT, Aiello-Lammens ME and others (2014) Life history and spatial traits predict extinction risk due to climate change. Nat Clim Change 4:217

Phillips C (2017) Ghostly encounters: dealing with ghost gear in the Gulf of Carpentaria. Geoforum 78:33-42

* Poisson F, Filmalter JD, Vernet AL, Dagorn L (2014) Mortality rate of silky sharks (Carcharhinus falciformis) caught in the tropical tuna purse seine fishery in the Indian Ocean. Can J Fish Aquat Sci 71:795-798

Q Queiroz N, Humphries NE, Mucientes G, Hammerschlag N and others (2016) Ocean-wide tracking of pelagic sharks reveals extent of overlap with longline fishing hotspots. Proc Natl Acad Sci USA 113:1582-1587

Rech S, Macaya-Caquilpán V, Pantoja JF, Rivadeneira MM, Jofre Madariaga D, Thiel M (2014) Rivers as a source of marine litter - a study from the SE Pacific. Mar Pollut Bull 82:66-75

Reid DD, Robbins WD, Peddemors VM (2011) Decadal trends in shark catches and effort from the New South Wales, Australia, shark meshing program 1950-2010. Mar Freshw Res 62:676-693

* Richardson K, Giskes I, O'Brien K, Ludwig L and others (2019) Building evidence around ghost gear: global trends and analysis for sustainable solutions at scale. Mar Pollut Bull 138:222-229

Romanov E, Bach P, Rabearisoa N (2010) Pelagic elasmobranch diversity and abundance in the Indian Ocean: an analysis of long-term trends from research and fisheries longline data. IOTC-2010-WPEB-16

Ryan PG, Moore CJ, van Franeker JA, Moloney CL (2009) Monitoring the abundance of plastic debris in the marine environment. Philos Trans R Soc B 364:1999-2012

Kaldanha HJ, Sancho G, Santos MN, Puente E and others (2003) The use of biofouling for ageing lost nets: a case study. Fish Res 64:141-150

Sazima I, Gadig OBF, Namora RC, Motta FS (2002) Plastic debris collars on juvenile carcharhinid sharks (Rhizoprionodon lalandii) in southwest Atlantic. Mar Pollut Bull 44:1149-1151

Schwartz FJ (1984) A blacknose shark from North Carolina deformed by encircling monofilament line. Fla Sci 47:62-64

Seitz JC, Poulakis GR (2006) Anthropogenic effects on the smalltooth sawfish (Pristis pectinata) in the United States. Mar Pollut Bull 52:1533-1540

Shahidul Islam M, Tanaka M (2004) Impacts of pollution on coastal and marine ecosystems including coastal and marine fisheries and approach for management: a review and synthesis. Mar Pollut Bull 48:624-649

Shiffman DS (2018) Social media for fisheries science and management professionals: how to use it and why you should. Fisheries 43:123-129

* Simpfendorfer CA, Milward NE (1993) Utilisation of a tropical bay as a nursery area by sharks of the families Carcharhinidae and Sphyrnidae. Environ Biol Fishes 37: 337-345

Skomal GB, Zeeman SI, Chisholm JH, Summers EL, Walsh HJ, McMahon KW, Thorrold SR (2009) Transequatorial migrations by basking sharks in the western Atlantic Ocean. Curr Biol 19:1019-1022

Skomal GB, Braun CD, Chisholm JH, Thorrold SR (2017) Movements of the white shark Carcharodon carcharias in the North Atlantic Ocean. Mar Ecol Prog Ser 580:1-16

Smith SDA, Edgar RJ (2014) Documenting the density of subtidal marine debris across multiple marine and coastal habitats. PLOS ONE 9:e94593

Smolowitz RJ (1978) Lobster, Homarus americanus, trap design and ghost fishing. Mar Fish Rev 40:59-67

Stelfox M, Hudgins J, Sweet M (2016) A review of ghost gear entanglement amongst marine mammals, reptiles and elasmobranchs. Mar Pollut Bull 111:6-17

* Stevens J, Bonfil R, Dulvy NK, Walker PA (2000) The effects of fishing on sharks, rays, and chimaeras (chondrichthyans), and the implications for marine ecosystems. ICES J Mar Sci 57:476-494

Stewart JD, Jaine FRA, Armstrong AJ, Armstrong AO and others (2018) Research priorities to support effective manta and devil ray conservation. Front Mar Sci 5:314

* Thiel M, Luna-Jorquera G, Álvarez-Varas R, Gallardo C and others (2018) Impacts of marine plastic pollution from continental coasts to subtropical gyres - fish, seabirds, and other vertebrates in the SE Pacific. Front Mar Sci 5:238

Thorrold SR, Afonso P, Fontes J, Braun CD, Santos RS, Skomal GB, Berumen ML (2014) Extreme diving behaviour in devil rays links surface waters and the deep ocean. Nat Commun 5:4274

* Tittensor DP, Mora C, Jetz W, Lotze HK, Ricard D, Vanden Berghe E, Worm B (2010) Global patterns and predictors of marine biodiversity across taxa. Nature 466: 1098-1101

*Vegter AC, Barletta M, Beck C, Borrero J and others (2014) Global research priorities to mitigate plastic pollution impacts on marine wildlife. Endang Species Res 25: 225-247

Votier SC, Archibald K, Morgan G, Morgan L (2011) The use of plastic debris as nesting material by a colonial seabird and associated entanglement mortality. Mar Pollut Bull 62:168-172

Wabnitz C, Nichols WJ (2010) Editorial: plastic pollution: an ocean emergency. Mar Turt Newsl 129:1-4

Wafar M, Venkataraman K, Ingole B, Ajmal Khan S, Loka Bharathi P (2011) State of knowledge of coastal and marine biodiversity of Indian Ocean countries. PLOS ONE 6: e14613

*Wegner NC, Cartamil DP (2012) Effects of prolonged entanglement in discarded fishing gear with substantive biofouling on the health and behavior of an adult shortfin mako shark, Isurus oxyrinchus. Mar Pollut Bull 64:391-394

* Werry JM, Planes S, Berumen ML, Lee KA, Braun CD, Clua E (2014) Reef-fidelity and migration of tiger sharks, Galeocerdo cuvier, across the Coral Sea. PLOS ONE 9:e83249

West J (2014) Shark attack theories. Taronga Conservation Society Australia, Mosman

*White WT, Appleyard SA, Kyne PM, Mana RR (2017) Sawfishes in Papua New Guinea: a preliminary investigation into their status and level of exploitation. Endang Species Res 32:277-291

Wilcox C, Hardesty BD, Sharples R, Griffin DA, Lawson TJ, Gunn R (2013) Ghostnet impacts on globally threatened turtles, a spatial risk analysis for northern Australia. Conserv Lett 6:247-254

*Wilcox C, Heathcote G, Goldberg J, Gunn R, Peel D, Hardesty BD (2015) Understanding the sources and effects of abandoned, lost, and discarded fishing gear on marine turtles in northern Australia. Conserv Biol 29:198-206

* Worm B, Davis B, Kettemer L, Ward-Paige CA and others (2013) Global catches, exploitation rates, and rebuilding options for sharks. Mar Policy 40:194-204 